\title{
Geoinformation Modeling of Soil Pollution by Lead Compounds in Highway Agroecosystems
}

\section{Geoinformation Modeling of Soil Pollution by Lead Compounds in Highway Agroecosystems}

\author{
Nataliia Korohoda*, Oleksandr Halahan
}

Taras Shevchenko National University of Kyiv, 2A, Glushkov Prospekt, Kyiv, 03680 Ukraine

\section{*Corresponding author: nkorogoda@ukr.net}

This work examines the method of geoinformation modeling in determining the degree of soil pollution by $\mathrm{Pb}$ compounds in the highway ecosystems, used as agricultural areas. The methodology allows identifying the spatial parameters of the area of pollution and the territories safe for cultivating crops by determining the actual level of soil contamination. The actual level of pollution (ALP) reflects the estimated balance of $\mathrm{Pb}$ compounds in soils over a specified period of time and the duration of pollution (or decontamination) period under the conditions of existing anthropogenic pressure. ALP is defined as the difference between the calculated amount of $\mathrm{Pb}$ compounds that have been introduced into the soils of the geosystems from the main sources of emissions and their calculated amount that has been lost from the soil and/or removed from migratory flows (by being transferred to the state conditionally inaccessible by plants), for the same time interval. Methodology verification took place in the geographic area representative of forest-steppe zone of Ukraine by its environmental conditions and agricultural use. Methodology implementation was conducted by building spatial regional databases, utilizing the data from field and laboratory soils studies and open sources of digital spatial data. Based on geoinformation modeling, we determined the configuration and quantitative characteristics of the primary zone of contamination of the soil surface layer with $\mathrm{Pb}$ compounds. We presented the calculation procedure of quantitative indicators of soil decontamination from $\mathrm{Pb}$ compounds as they redistribute through the soil profile via main geochemical scenarios. We also provided the rate of this process under the conditions of the existing anthropogenic pressure. Using modeling results, we mapped areas of removal, transit and accumulation of $\mathrm{Pb}$ compounds and territories receiving pollution from highway geosystems. Verification of the modeling results during laboratory studies proved the objectivity of the proposed methodology in determining the current levels of pollution with $\mathrm{Pb}$ compounds. Our methodology could be utilized for a set of different environmental factors as well as other heavy metals with a purpose of identifying areas safe for cultivating crops.

Keywords: Pb compounds, geoinformation modeling, actual level of contamination, highway geosystems. 


\section{Introduction}

The protection, regulation and planning of the landscapes were recognized by the European Landscape Convention as primary tasks in future landscape management (European Landscape Convention, 2000). These tasks formulate the relevant missions for modern environmental studies, in particular: preservation and maintenance of key features of the landscapes, provision of constant care of the landscapes and implementation of the measures to improve the future state of landscapes. Such tasks determine the need to identify changes in the levels of pollution of individual landscape components that are necessary to understand in order to maintain landscape's current and future stable states.

One of these components is the soils, which most frequently concentrate flows of chemical elements, thus linking the landscape and geochemical systems into a single whole. In addition, the soil can act as a natural buffer that controls the transfer of chemical elements to other components of geosystems, where soil properties determine the rate of movement of chemical elements.

Heavy metals (HM) including $\mathrm{Pb}$ are elements that form the ecological state of soils near highways. After all, vehicle emissions for a long time were, and some places remain, the main source of HM pollution. In recent decades, elemental inputs have declined significantly as a result of increasing fuel quality requirements (DieselNet, 2017). Nevertheless, soil pollution with $\mathrm{Pb}$ compounds remains to be a problem because, firstly, $\mathrm{Pb}$ compounds continue to get into soil with vehicle emissions, although in small quantities and, secondly, the HM compounds have a tendency to accumulate in soils because of prolonged residence time. These features explain a rather frequent phenomenon of harmfully excessive current concentrations of $\mathrm{Pb}$ compounds in soils near highways. The characteristic quality of these compounds is their negative effect on the state of soil organic matter (Chibuike and Obiora, 2014). In addition, under certain conditions, $\mathrm{Pb}$ could freely migrate between the components of the geosystems, in particular, to be absorbed by plants (Minkina et al., 2011), including crops, because agricultural lands are often located within the influence of roads. Consumption of plants grown near the roads is unsafe for people because $\mathrm{Pb}$ compounds are toxic and capable of accumulating in the body. Therefore, the study of redistribution of HM compounds in soils of highway geosystems is an important area in environmental and geochemical research. Thanks to such research, it is possible to identify agricultural lands that are safe for growing agricultural crops, as these are essential for Ukraine in the light of the opening of European markets.

The research of the pollution of geosystems by HM compounds along highways continues to attract the attention of scientists around the world. In particular, topics of interest include the formation of a general area of pollution along the highways (Pagotto et al., 2001) including cities (Duong and Lee, 2011; Vlasov, 2017), and the link between the level of soil pollution and other components of the geosystem, in particular, vegetation cover (Minkina et al., 2011; Pivić et al., 2013; Viard et al., 2004). Separate research is focused on the quality of agricultural lands in the area of influence of highways (Nath, 2015). As these and other studies show, the general trend is reduced concentrations of pollutants in soils with an increased distance from the source of emission. However, often territories located further from the source have higher concentrations of pollutants due to the redistribution of pollutants in the soils following the main geochemical scenarios (Sorokina, 2008). The difficulty assessing the state of geosystems and the rate of their pollution is associated with the permanent nature of the inputs of pollutants into the geosystems and the heterogeneity of redistribution mechanisms of pollutants in soils. This necessitates the implementation of model construction with the use of GIS technologies (Faccinelli et al., 2001), in particular, when determining the spatial characteristics of the area of pollution.

In our previous work (Galagan, 2013a, 2013b, 2014a, 2015; Halahan and Korohoda, 2014b), we suggested using modeling while taking into account the leading factors of input and the main mechanisms for the decontamination of geosystems. Such modeling would 
allow calculating the HM balance in geosystems and determining the actual levels of geosystems contamination. However, the model requires validation to make sure it works for the territories with a variety of physio-geographical conditions, and therefore a variety of geochemical scenarios of redistribution of heavy metals in soils. The purpose of this work was to implement the aforementioned modeling in typical forest-steppe conditions of Ukraine covering approximately $30.3 \%$ of the Ukrainian plains and containing predominantly agricultural land.

The objectives of this study were as follows: 1) to determine the main provisions of the methodology of geoinformation modeling while identifying the actual levels of soil pollution by HM compounds; 2) to model the actual level of pollution for the study area with typical forest-steppe environmental conditions; 3) based on modeling results, to identify agricultural lands that are safest for planting; and 4) to identify geographic distribution and determine the levels of HM compound contamination for those geosystems that do not fall directly into the zone of influence of roads, yet are subjected to pressure from highway geosystems.

\section{Methods}

Properties of heavy metals and the landscape-geochemical conditions determine territorial spread and behavioral mechanisms of vehicle emissions as well as the effectiveness of landscape-geochemical methods for assessing the spread of pollutants in geosystems (Sorokina, 2008). In our recent work, we have recommended a method for identifying areas that are safe for cultivation of crops by determining the actual levels of soils pollution of geosystems by $\mathrm{Pb}$ compounds. The actual level of pollution (ALP) is calculated as the difference between the computed amount of $\mathrm{Pb}$ compounds that have been introduced into the soil of geosystems from the main sources of pollution and their estimated amount that has been removed from the soil and/or migratory flows (transferred to form conditionally inaccessible by plants), for the same time interval (Halahan, 2017). Thus, ALP reflects the estimated balance of $\mathrm{Pb}$ compounds in soils of the highway geosystems over a specified period of time as well as the change of the level of pollution, that is, the rate of pollution (or decontamination), under the conditions of existing anthropogenic pressure. To determine the ALP, we propose using the general modeling algorithm (1).

Poll.h.m. = Cont.h.m. - Cl.h.m

where: Poll.h.m. - the indicator of ALP; it reflects the quantity of HM that changes the level of pollution in highway geosystems under the conditions of existing anthropogenic pressure; Cont.h.m. - the indicator of contamination; it characterizes the estimated quantity of HM introduced into soil of geosystems with vehicle and industrial emissions from agriculture as well as from migration of HM compounds from geosystems located above in catenary conjugation for a certain period of time; Cl.h.m. - the indicator of decontamination; it is based on the properties of the geosystem components and characterizes the estimated amount of HM that have been removed from soil and/or migratory flows (transferred to a form conditionally inaccessible by plants) for the same time interval as Cont.h.m. (Halahan, 2017).

The ALP calculated as a difference between Cont.h.m. and Cl.h.m. allows identifying the term during which the change of the level of soil pollution with $\mathrm{Pb}$ compounds will occur.

Each model indicator corresponds to a certain stage in geoinformation modeling supporting its own models and methods: acquisition, accumulation, preservation (in the form of an electronic database), analysis and display of interim and final modeling results. Geoinformation modeling, unlike others, allows determining the spatial parameters of the area of pollution and calculating the "density of phenomenon" on the studied territory, as well as the dependence between several geoparameters, for example, the characteristics of the terrain and the accumulation of chemical elements (Galagan, 2013a).

In the general process of modeling, the main geoinformation and mathematical models were used to describe the distribution patterns of heavy metals in geosystems: 
Models of spatial distribution of heavy metals in the atmospheric air from a technogenic sources of emissions, particularly, models based on equations of turbulent diffusion (Berliand's model). The parameters used in this model are both the intensity of the emission source and the physical and geographical factors of impurity distribution, in particular, the relief and microclimatic characteristics of the territory (including wind speed and direction). As such, the use of this model allows obtaining the spatial characteristics and intensity of the primary area of pollution. However, the methodology could use the dispersion of an impurity by Gaussian formulas, recommended by the European Economic Community and the meteorological services of many countries.

Erosion models that describe the movement of insoluble soil compounds in the scenarios of lateral migration and could be used to study the behavior of bound heavy metals (Kovalchuk et al., 2009; Mkrtchyan, 2004). These models take into account such parameters as: 1) concentrations of lead compounds in the surface layer of the soil; 2) properties of soils that determine their erosion resistance and migration ability of pollutants: mechanical composition, permeability, structure, humus content, etc.; 3) topographic factors of the terrain that determine the rate of erosion processes, namely slope shape, length and gradient; 4) the amount of annual precipitation and its type, which determine its erosion capacity; 5) the presence and type of vegetation in the area.

Models that describe the biogenic migration of substances in the geosystem, in particular, the migration of heavy metals in the soil-plant system. Biological absorption coefficient is the parameter used in such models.

The verification of the simulation technique took place during the field studies of soil characteristics in field sites (samples of soils were collected at 109 sites) containing landscape conditions representative of the $\mathrm{Pb}$ compound migration direction and the migration rate. Soils were selected from the upper horizons $(0-20 \mathrm{~cm})$. We conducted laboratory studies of soil characteristics to determine the migration conditions of $\mathrm{Pb}$ compounds $(\mathrm{pH}$, granulometric composition, humus content). We also conducted laboratory analysis of the soil samples to determine the concentration of $\mathrm{Pb}$ in the soils. Contents of $\mathrm{Pb}$ compounds were determined using X-ray fluorescence (Anjos et al., 2000) and atomic absorption spectrophotometry (Minkina et al., 2011). These studies were conducted with the aim of identifying the key conditions of migration of $\mathrm{Pb}$ compounds in soils of the test area and examining the provisions of the modeling methodology. The studies have completely confirmed the spatial characteristics of the area of pollution, modeled using the recommended methodology.

To model the processes in this site, we created spatial databases based on the Google Earth and OpenStreetMap cartographic web services. In addition, we used thematic bitmap electronic maps that we vectorized. The initial scale for mapping was 1:10,000.

In order to calculate the actual levels of soil pollution by $\mathrm{Pb}$ compounds in highway geosystems, we determined the quantitative characteristics of the first component of the model algorithm (1). This component reflected the total quantity of $\mathrm{Pb}$ compounds brought into the geosystem. The method of calculating the first model index Cont.h.m. and specifying HM quantity, taking into account the main ways of their input (vehicles, industry, agriculture and geosystems, which are at the highest hypsometric level and can become the source of contamination as a result of migration of pollutants), was previously presented in our work (Halahan, 2017). Natural and anthropogenic factors affecting the amounts of $\mathrm{Pb}$ compounds coming from vehicles and the methods for refining their amounts were presented in the paper (Halahan and Korogoda, 2018).

After obtaining the quantitative values of the inflow of $\mathrm{Pb}$ compounds to lower atmospheric layers, we used a model of dispersion of impurities in the atmosphere (Galagan, 2014) and determined the surface area of the near-to-earth atmospheric layers affected by contamination (Halahan and Korohoda, 2014b). Then, we calculated the quantity of $\mathrm{Pb}$ compounds deposited from the atmospheric layers to the soil surface using regression analysis. Regression equations were used because the metals content in the near-to-earth 
atmospheric layers reliably correlates with their concentrations in the upper layer of soil (Halahan, 2015).

Because $\mathrm{Pb}$ compounds in soils could be present in both soluble and insoluble forms and their redistribution occurs via pathways of lateral and radial migrations, fixation on geochemical barriers, and biogenic migration, there is a need to model all of these scenarios. Consequently, the modeling process of indicator Cl.h.m. includes the following steps with the creation of the corresponding database modules:

1 Decontamination of soils from $\mathrm{Pb}$ compounds as a result of lateral migration. This module makes it possible to determine the levels of $\mathrm{Pb}$ compounds removed from the geosystems (Svetlichny et al., 2004).

2 Decontamination of soils from $\mathrm{Pb}$ compounds as a result of radial migration. This module utilizes methodology from Methodendokumentation "Bodenkunde" (2000) and makes it possible to determine:

areas where migration of soluble forms of lead occurs;

intensity of migration processes;

the level of safety concern associated with the use of area for agriculture.

3 Decontamination of soils from $P b$ compounds as a result of fixation on geochemical barriers. This module makes it possible to determine the amounts of $\mathrm{Pb}$ compounds to be removed from migratory elemental flows.

4 Decontamination of soils from $\mathrm{Pb}$ compounds as a result of biogeochemical processes. This module allows determining the quantity of HM removed from the geosystems (for example, with the harvest) and the degree of pollution of agricultural crops.

Calculation and geoinformation modeling of the level of $\mathrm{Pb}$ compounds removed from the geosystem as a result of lateral migration is necessary for those HMs that are in an insoluble form. It is necessary to determine the direction and intensity of mechanical lateral migration of such compounds in the studied area. Based on these data, we compiled a map of Redistribution of $\mathrm{Pb}$ compounds in the surface layer of soils as a result of mechanical lateral migration. In our calculations, we utilized the methodology of determining the amounts of soils eroded from the area (Kovalchuk et al., 2009; Mkrtchyan, 2004).
The parameters we took into account included the size of the primary area of the soil's surface layer contaminated with $\mathrm{Pb}$ compounds and processes affecting the mechanism of soil decontamination as a result of lateral migration. Such a mechanism is characterized by factors that determine the erosion resistance of soils and the intensity of erosion processes, namely, physical and chemical properties of soils (mechanical composition, drainage properties, structure, humus composition), terrain features (length and tilt of the slope), hydro-climatic characteristics of the territory (the nature and extent of annual precipitation) and vegetation type (its presence and species composition). The application of these indicators gives the opportunity to calculate the amount of soils removed from a particular area over a certain period of time and, accordingly, the quantity of HM in an insoluble form moved with a total weight of soil.

For model construction, we utilized a relational geodata database containing information on the properties of soils including attribute characteristics determining erosion susceptibility. For the soils in the study area, we determined coefficients that reflect the conditions supporting the flow of mechanical lateral migration. These formed the attribute components of the database and included the following: potential erosion coefficient $(K b)$, soil skeletal coefficient (Ks), terrain topographic factor $(L S)$, erosion index of precipitation $(R)$, coefficient of vegetation influence $(C)$, and factor of anti-erosion measures $(P)$. Based on these data, an overlay with appropriate thematic layers was performed. The indicator Efw was determined from the eroded soil mass (metric tons) per unit area (hectare) over a time period (year) using formula (2) (Methodendokumentation "Bodenkunde", 2000).

$E f W=K b \cdot K S \cdot L \cdot S \cdot R \cdot C \cdot P$

The overlay analysis of the digital soil map (the value of EfW) and the map Contamination of the surface layer of soils... allowed determining the amount of $\mathrm{Pb}$ compounds removed by mechanical lateral migration in this time period (Ehm) as (3).

$E h m=E f w \cdot y$

where: indicator Efw - the amount of soil that is removed from the area; $y$ - the concentration of $\mathrm{Pb}$ compounds in the surface layer of soil. 
In geoinformation modeling, we utilized a digital relief map to create a digital model of the terrain of the territory in the form of an irregular triangulation network (TIN) following the Delaunay triangulation algorithm (Galagan, 2013a). The number of triangles in the study area was 102,524. Each triangle in such a network was a part of the surface with unique and homogeneous spatial characteristics, which made it possible to treat it as the minimum parcel in mathematical modeling. Further, the calculations of all parameters were carried out in the indicated triangles as average values, weight by areas of triangles. In particular, the slope length I (m) and slope tilt s (\%) were identified in each triangle and, accordingly, the relief-dependent migration factor LS was calculated.

Overlay analysis of the triangulation network and the map Contamination of the surface layer of soils... allowed the corresponding values of the pollution area in each parcel to be obtained. In order to determine the quantity of $\mathrm{Pb}$ compounds that migrate in the scenario of lateral migration, overlays with digital maps Contamination of the surface layer of soils, Soils, and Plant cover were conducted for the study sites. Based on this analysis, we calculated:

a the coefficient of potential erosion of soils Kb, with the help of our calculation module database, which was based on the nomogram of Wischmeier, Jonnson and Cross;

b The amount of soil (EfW) and $\mathrm{Pb}$ compounds (Ehm) that could potentially be removed from the site through erosion processes, according to formulas $(2,3)$. This step fulfilled our modeling goal, which was the determination of quantitative indicators of soil decontamination from $\mathrm{Pb}$ compounds as a result of the lateral migration.

It should also be taken into account that for every "lower" in the catenary conjugation a certain amount of HM gets into the site from the "higher" catenary link, and then, along with $\mathrm{Pb}$ compounds, directly from anthropogenic emissions sources migrate downslope. This algorithm made it possible to calculate the mechanical redistribution of heavy metals in the surface layers of the soil. A separately developed specialized module allowed determining the direction of movement of matter and building a graph of "lateral migration between parcels". Because the algorithm takes into account migration of Pb from the "higher" catenary link, it was possible to calculate total $\mathrm{Pb}$ input as a sum of $\mathrm{Pb}$ amounts accumulated on the surface of the soil directly from the air and $\mathrm{Pb}$ amounts that migrated downslope. The residual amounts of lead were calculated as the difference between inputs and outputs of HM in the process of lateral migration. This algorithm allowed calculating the parameters of the decontamination of geosystems, but also helped to determine the final component of the equation, namely the size of the influx of $\mathrm{Pb}$ compounds that enters the soil from the conjugated geosystems.

The values of the "contamination - decontamination" parameters for geosystems in general were obtained as averages weighted by the areas of triangles. As a result, the thematic layer Redistribution of $\mathrm{Pb}$ compounds in the surface layer of soil as a result of lateral migration was received; it reflects the residual HM quantities in the geosystems, as well as zones of lead mobilization, transit, and accumulation.

However, only a comprehensive analysis of lateral and radial redistribution makes it possible to identify areas harmful to humans, since in some places, the highest index of heavy metal content in the soil is not critical for growing agricultural products. On the other hand, insignificant content of HM in the soil, under certain conditions, is the source of the greatest potential safety concern for plant crop pollution. Accordingly, the next step in the implementation of the methodology was to determine the magnitude of the redistribution of $\mathrm{Pb}$ compounds in the surface layer of soils during the radial migration. The process of radial migration of lead compounds could be accelerated in presence of certain characteristics of the geosystem's components, in particular soil acidity, fulvic type of humus, lightweight mechanical properties, lack of carbonates, etc. In addition, any of these factors may act as limiting and, accordingly, either slow down or completely halt the radial migration process.

The calculations were carried out as follows:

for each indicator of $\mathrm{pH}$ in soil, according to the method (Methodendokumentation "Bodenkunde", 2000), the so-called "binding score" $\left(B_{(\mathrm{pH})}\right)$ was provided (Table 1). The individual ability of metals to turn into a 
soluble form and migrate with different indicators of the acidic reaction of soil determines the attribute $B_{(p H)}$. For example, the mobility of $\mathrm{Pb}$ is limited by a geochemical barrier, if the $\mathrm{pH}$ of the salt extraction is higher than 4.2. The conditions in such a substrate are unfavorable for radial migration of $\mathrm{Pb}$, hence its redistribution will be mainly in the scenarios of lateral migration.

If the $\mathrm{pH}$ level is less than or equal to the limit (for example, the lead-binding score is 4.0 (Table 1.)), the compounds are in a soluble form; therefore, in such conditions, the process of their radial migration is accelerated. In this case, it is necessary to analyze the possibilities of binding soluble compounds of heavy metals by soils, due to other properties of humus, granulometric composition, etc. As a result of determining the level for each of these indicators, for each type of soil, it is possible to obtain an attribute that characterizes the relative degree of binding $\left(B_{\text {(totall }}\right)$ and the magnitude of the radial migration of the HM.

Table 1. Binding scores for Pb compounds as controlled by soil acidity, based on (Methodendokumentation "Bodenkunde", 2000)

\begin{tabular}{c|c|c}
\hline $\mathrm{pH}$ of the salt extraction & Binding score $\mathrm{B}(\mathrm{pH})$ & Migration of soluble forms of $\mathrm{Pb}$ \\
\hline$<2.5$ & 0 & Very fast \\
\hline $2.5-2.7$ & 1 & Fast \\
\hline $2.8-3.2$ & 2.0 & Accelerated \\
\hline $3.3-3.7$ & 3.0 & Normal \\
\hline $3.8-4.2$ & 4.0 & Difficult \\
\hline higher than 4.2 & 5.0 & Conventionally absent \\
\hline
\end{tabular}

Overlay analysis of the thematic layers Contamination of the surface layer of soils ... (see above) and the digital map of soil ( $\left.B_{(\text {total) }}\right)$ make it possible to determine the degree to which soils in geosystems are unsafe from the point of view of growing plants for food consumption.

Next step in the implementation of modeling is the determination of the amount of $\mathrm{Pb}$ removed from soils as a result of biogenic migration, that is, the fraction of metals quantity absorbed by plants. The information basis for this modeling phase is the digital map of the vegetation (attribute of the coefficient of biological absorption (CBA)).

Overlay analysis of vegetation map and Contamination of the surface layer of soil... map makes it possible to calculate the amount of HM that plants will absorb from soils. After all, in the sites characterized by the processes of radial migration of HM compounds, depending on the magnitude of this process $\left(B_{\text {(total })}\right)$, up to $100 \%$ of the pollutants have the potential to be absorbed by plants. At the same time, in areas where such migration is conventionally absent, only about $10 \%$ of metals have the ability of soils-to-plant migration (Minkina et al., 2011). Thus, it is possible to determine the quantity of metals potentially harmful from the point of view of the soils-to-plants transfer. It is also possible to model the process of biogeochemical migration, having its geoinformation represented by the maps Accumulation of $P b$ compounds by plants and Decontamination of soils from $\mathrm{Pb}$ compounds in the process of biogenic migration.

The step-by-step implementation of the partial modeling allowed calculating the actual level of pollution $(A L P)$ as the difference between the amount of $\mathrm{Pb}$ compounds input to the soils in the highway geosystems of the study area (Cont.h.m.) and the amount that was removed from the soils and/or transferred from the matter-energy flows (Cl.h.m.) over the course of the year. In determining the ALP, we chose 1 year as a calculation period because we assumed this length of the study period is long enough to allow all factors affecting changes in soils to manifest themselves. 


\section{Results and Discussion}

For the modeling of the field pollution process within the environmental zone of the forest-steppe, we selected a site located within the international highway M-05 "Kyiv-Odesa" between kilometer posts 91 and 96 of Kyiv Oblast, Bila Tserkva rayon.

The environmental conditions, agricultural practices, recreational and subsistence uses of the area make it possible to speak of the representativeness of our choice. This area is represented by the environmental features that are typical of the forest-steppe zone like pronounced valley, terrain intercepted by ravines and gullies, and soils with neutral $\mathrm{pH}$ and humic type of humus, characterized by heavy mechanical composition. In terms of land use, the area is mainly represented by arable lands. Among the crops cultivated in this area, the dominant are cereals (with highest ratio of wheat, rye, corn and buckwheat), potatoes, sunflowers, sugar beets, soybeans, rapeseed, and several types of vegetable.
The amounts of $\mathrm{Pb}$ compounds released into the air from the vehicle emissions at the study site were calculated based on methods developed by Halahan and Korogoda (2018). Additional sources of Pb compounds of anthropogenic origin in the year of observation were not identified as part of the analysis of industry and agriculture in the region of study. Regarding the last of the main sources of $\mathrm{Pb}$ compounds in the soils of the highway geosystems on catena, at the highest hypsometric level, we note the following: this indicator was modeled as part of the calculations of the amount of $\mathrm{Pb}$ compounds transferred in soils as a result of mechanical lateral migration (see above).

Based on calculations and overlay of digital maps Pollution of the layer of atmospheric air and Soils, a map Contamination of the surface layer of soil from atmospheric air was constructed (Fig. 1). This map shows the concentrations of $\mathrm{Pb}$ compounds in a 20 -centimeter layer of soil, which gives an idea of the

Fig. 1. Contamination of the surface layer of soil from the air

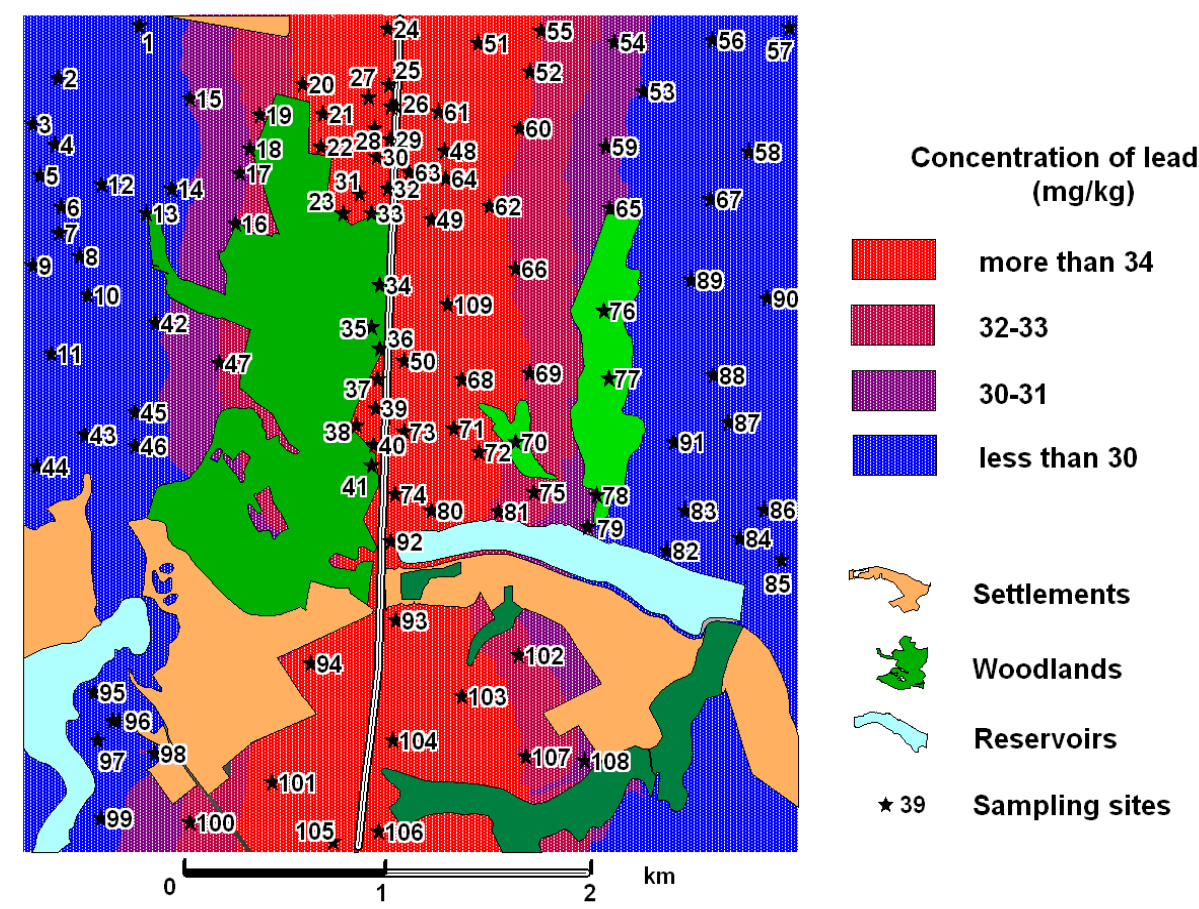


configuration and quantitative characteristics of the primary area of pollution of the surface layer of soils with $\mathrm{Pb}$ compounds.

The surface, shown in Fig. 1, became the basis for determining the model index Cl.h.m. (1), which characterizes the processes of soil decontamination.

Typical for the study site are geosystems represented by plains on loess' with different types of chernozems, mostly cultivated. These geosystems occupy the highest gipsographic level of the territory and are characterized by the extraction of insoluble $\mathrm{Pb}$ compounds with sheet erosion. Erosion is activated in steep areas, where intensity is determined by the increase in the surface slope. On slopes of varying degree of tilt on loess with different types of chernozems, which are predominantly cultivated slopes, geosystems are the most dynamic in terms of the rate of lateral migration of insoluble $\mathrm{Pb}$ compounds. They act as zones of removal (top facets), transit (mid-section) or accumulation (bottom facets), depending on the slope steepness, type and phase of vegetation development, and prevalent land use of geosystems. Terraces form on sediments of deluvial with glaysolic dark-grey alfisol under meadow vegetation whereas floodplains form alluvial sediments with wetland carbonate loam under marsh vegetation. Terraces mainly accumulate the pollutants, which could be explained by both their hypsographic position and features of the terrain. Low, predominantly swampy floodplains accumulate $\mathrm{Pb}$ compounds that are removed from top facets of catena geosystems. Low swampy floodplains and peatlands are accumulative, due to high content of organic matter.

Fig. 2. Self-decontamination potential (through lateral migration) of highway geosystems

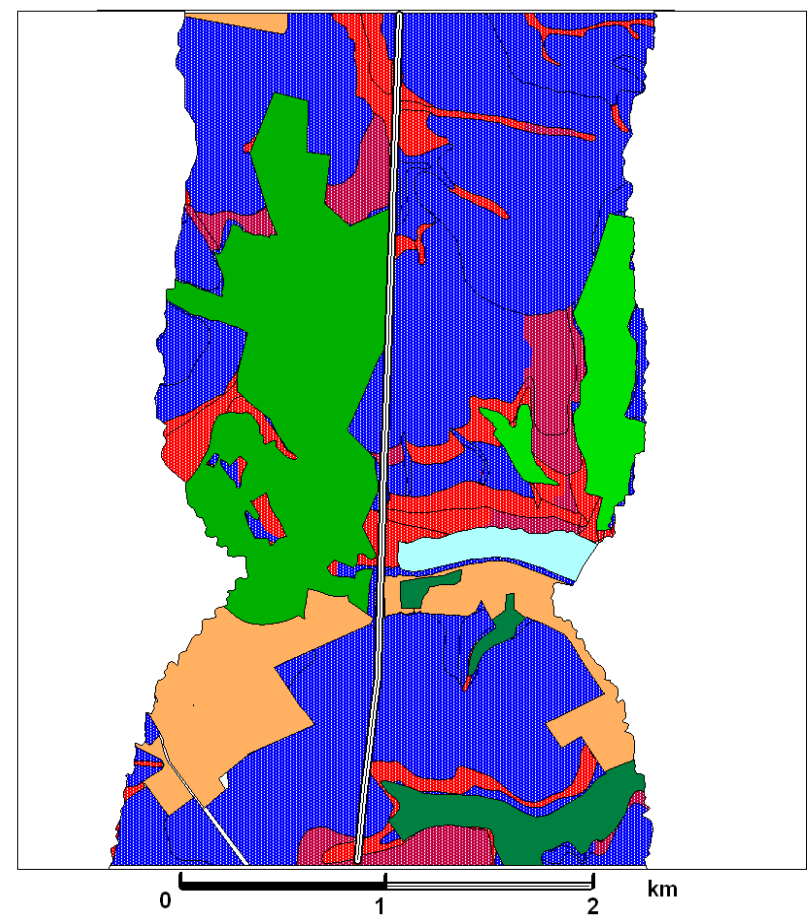

Level of possibilities

for self-purification in the process of lateral migration

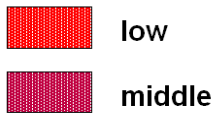

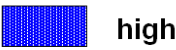

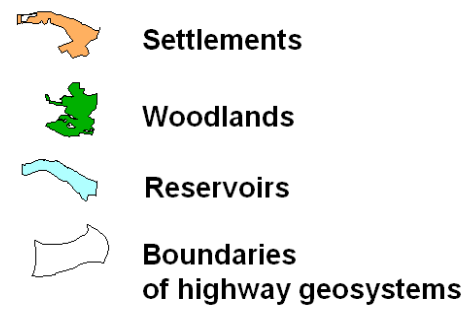

Geosystems of erosive origin are as follows: gullies, on loess with eroded soils of gullies and arroyos under oak forests, bottom of arroyos on loess with carbonate accumulated as result of erosion dustyloam soils, cultivated, where in some places the accumulation of pollutants is observed. In the geosystems 
of the erosion network, $\mathrm{Pb}$ concentrates in apical catchment, its concentration decreases down the profile and then increases again in the alluvial fans. This phenomenon occurs due to the active washing of the bottom of the erosion forms in their middle part and the heavier mechanical composition of the ploy material. It should be noted that high rates of sprouting lead to widespread acceleration of water erosion processes and the flushing of the fertile soil layer in the study site.

Depending on the relationship between HM input and removal rates, geosystems with a various level of self-decontamination capabilities as a result of lateral migration were identified. Figure 2 shows sections of the landscape characterized by a high level of self-decontamination potential, associated with the rate of HM removal that exceeds the rate of input, a moderate level, associated with relatively similar rates of HM input and removal, and a low level, associated with the high rate of input and low rate of removal.

During the analysis of soil properties in the study area, it was determined that the local pH level above 4.2 does not allow $\mathrm{Pb}$ compounds to transfer into a soluble form, causing the formation of geochemical barriers for soluble forms of $\mathrm{Pb}$ compounds, hence almost removing the potential for radial HB migration. In the conditions prevalent in the test area, where the level of migration of soluble forms of lead is defined as "conventionally absent", about 10\% of metal compounds could be absorbed by the root systems of plants. Therefore, in order to determine the quantity that could be removed from the soils as a result of biogeochemical processes, an overlay analysis of vegetation maps of the study site (attribute "CBA") and Contamination of the surface layer of soil ... was conducted. This specific assumption, i.e., "CBA*10\% $\mathrm{Pb}$ ", made it possible to calculate the quantity of $\mathrm{Pb}$ compounds that could be absorbed by plants from the soil and allowed completing a modeling module Decontamination of soils from $\mathrm{Pb}$ as a result of biogeochemical processes.

The modeling results are shown in Figure 3. They provided the current levels of soil pollution by $\mathrm{Pb}$ compounds in highway geosystems, as a reflection of the pollution and decontamination rates. The rate in this figure is given in relative units (\%) for greater visibility,

Fig. 3. The actual level of pollution by $\mathrm{Pb}$ compounds in highway geosystems

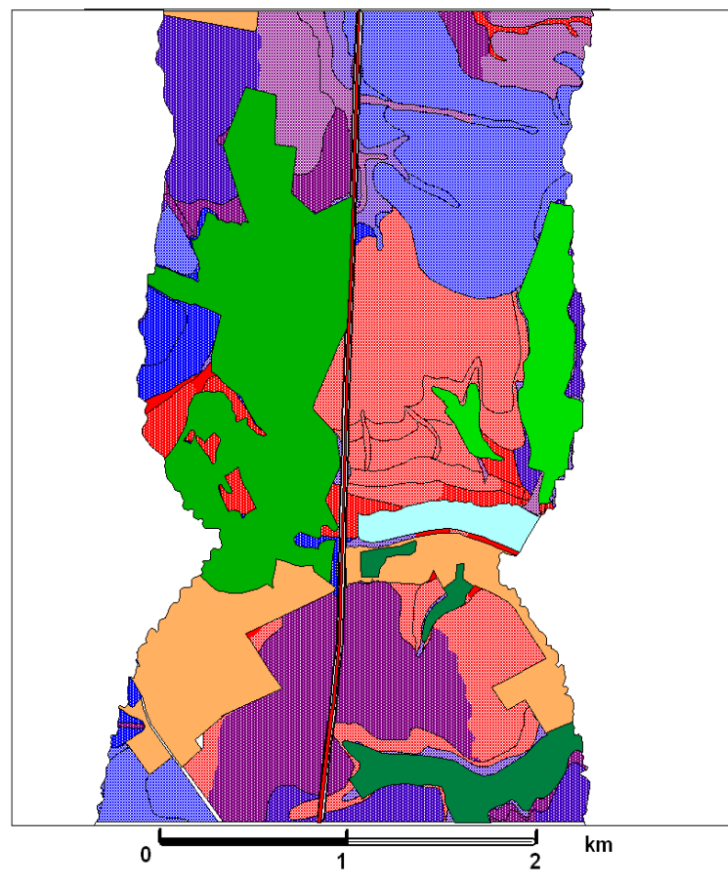

Actual level of pollution

(speed of purification (\%))
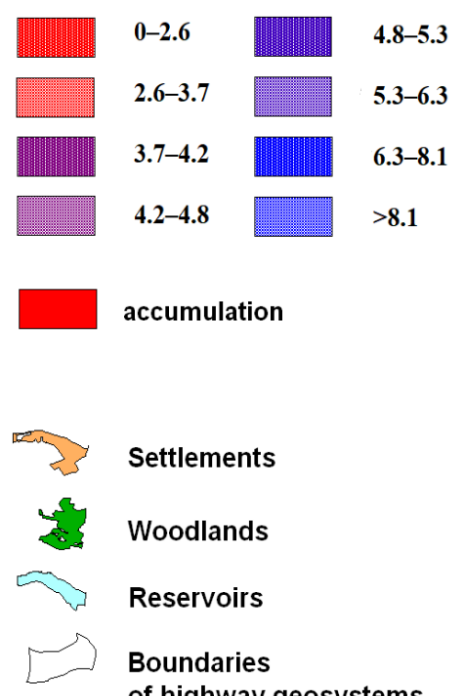

Settlements

Woodlands

Reservoirs

Boundaries

of highway geosystems 
whereas calculations were conducted using absolute units $\left(\mathrm{g} / \mathrm{m}^{2} /\right.$ year). The obtained values of ALP allowed reaching the study goals as to create the appropriate series of digital maps identifying areas capable of self-decontamination and to determine the rate of self-decontamination at the existing level of anthropogenic pressure. In the areas along highways, the accumulation of $\mathrm{Pb}$ compounds is associated with $\mathrm{HM}$ redistribution and is dependent on its rate, which could help to identify the potentially harmful zones for the cultivation of agricultural crops in highway geosystems. This rate could also help to identify and estimate pollution characteristics of areas harmful to cultivation of agricultural crops that are outside of direct zones of road influence, yet are affected by highway geosystems as a result of HM migratory processes (Fig. 4).

Fig. 4. Areas affected by highway geosystems due to migration of $P b$ compounds
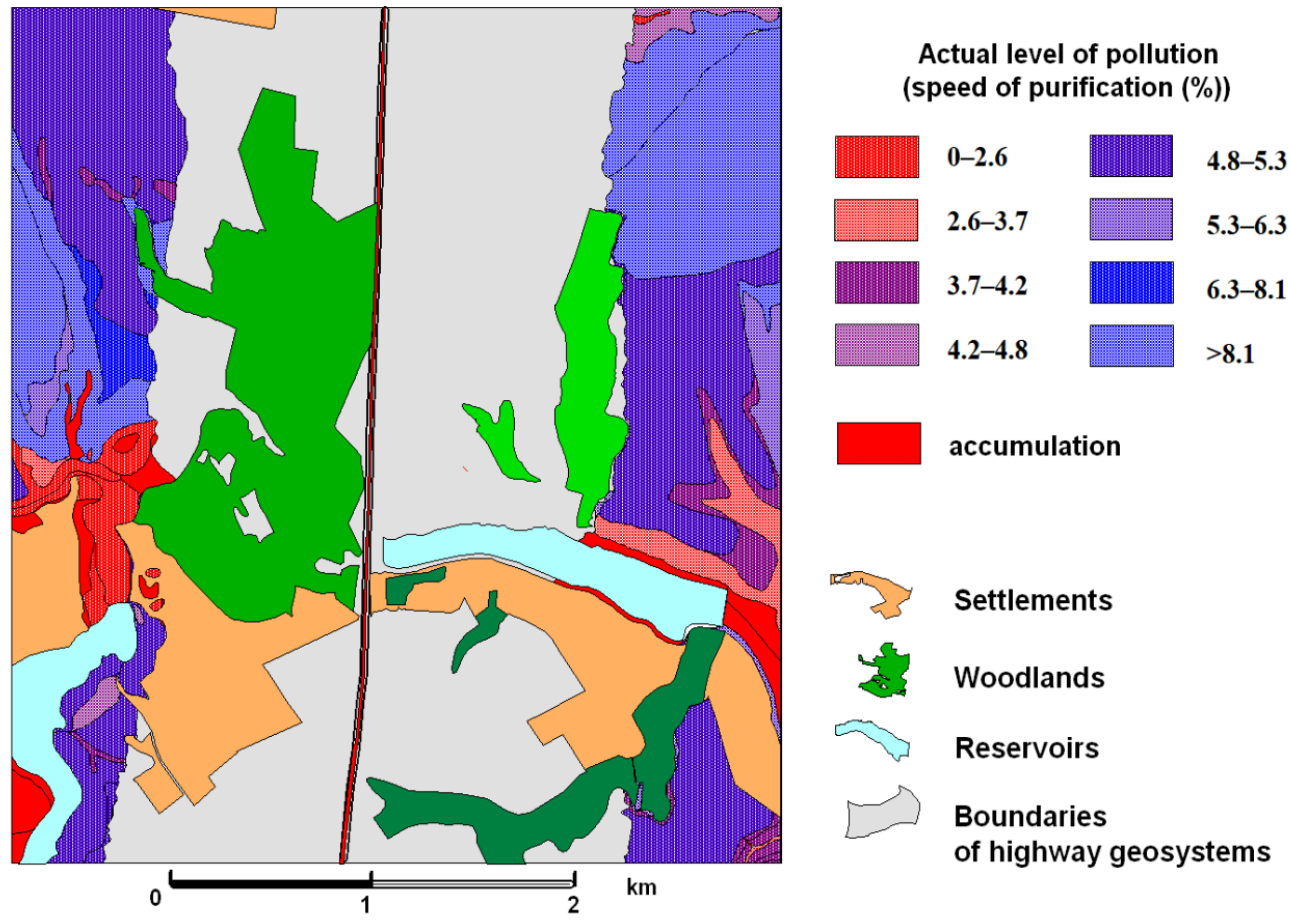

\section{Conclusions}

In the course of this study, we applied the methods of geoinformation modeling of ALP, created a series of digital maps, and identified areas potentially harmful for growing agricultural crops at the current level of anthropogenic pollution load in the environmental conditions of forest-steppe zone. Relatively often, these are areas located far from highways, where soil contamination occurs due to the lateral redistribution of pollutants. This process is controlled by the landscape features, primarily the nature of the relief and physicochemical characteristics of soils, rather than "direct influence of the highway." About 35\% of the area that represents the study site is characterized by a relatively high degree of ALP. These areas mainly include eluvial and transeluvial geosystems where the rate of decontamination exceeds the rate of $\mathrm{Pb}$ input. 
In $60 \%$ of the area, soils have moderate ALP values (the rate of contamination is approximately the same as the rate of decontamination). Obviously, this is due to both the number of pollutants and the peculiarities of their redistribution in geosystems. The modeling results presented in this work corresponded with the results of soil laboratory studies, which is an indication of the objectivity of the proposed methods of geoinformation modeling in determining the relevant level of soil pollution of agroecosystems by heavy metals.

\section{References}

Anjos M.J. et al (2000) Quantitative analysis of metals in soil using X-ray fluorescence. Spectrochimica Acta Part B: Atomic Spectroscopy 55 (7), 1189 -1194. https://doi.org/10.1016/ S0584-8547(00)00165-8

Chibuike G. U. and Obiora S. C. (2014) Heavy Metal Polluted Soils: Effect on Plants and Bioremediation Methods. Applied and Environmental Soil Science: Article ID 752708. https://doi. org/10.1155/2014/752708

DieselNet. Emission standards. EU: cars and light trucks (2017). Available at: https://www.dieselnet.com/standards/eu/ld.php

Duong T.T., Lee B.K. (2011) Determining contamination level of heavy metals in road dust from busy traffic areas with different characteristics. Journal of Environmental Management 92 (3): 554-562. https://doi.org/10.1016/j.jenvman.2010.09.010

European Landscape Convention (2000) .- Available at: https:// rm.coe.int/CoERMPublicCommonSearchServices/DisplayDCTMContent?documentld=0900001680080621

Facchinelli A. et al. (2001) Multivariate statistical and GIS-based approach to identify heavy metal sources in soils. Environmental Pollution 114 (3): 313-324. https://doi.org/10.1016/S02697491(00)00243-8

Galagan 0.0. (2013a) Modeling of the heavy metals distribution in the highway geosystems (in Ukrainian). Physic Geography and Geomorphology 2 (70): 28-33 / Галаган 0.0. Моделювання розподілу важких металів у приавтомагістральних геосистемах. Фізична географія та геоморфологія, 2013, вип. 2 (70), C.28-33

Halahan 0.0. (2013b). Comprehensive assessment of heavy metals redistribution in highway agrolandscapes (in Ukrainian). Social-ecological problems of the transition to sustainable development: realities and perspectives of the XXI century. International scientific-practical conference, Yalta, 24-27 Sep
Such modeling could be implemented in environmental management projects, since the offered method could be applied to any other heavy metal and other physio-geographical conditions. The modeled level of ALP allows establishing the optimum level of anthropogenic pressure in order to maintain highway geosystems in a steady state, current and prospective locations for safe crop production, etc.

\{Gurauskiene, 2006, Eco-design methodology for electrical and electronic equipment industry\}

2013: Theses Add: 33-35 / Галаган 0.0. Комплексна оцінка перерозподілу важких металів у приавтомагістральних агроландшафтах / Соціально-екологічні проблеми переходу до сталого розвитку: реалії та перспективи XXI століття: Міжнар. наук. - практ. конф., Ялта, 24-27 вер. 2013: тези доп., С. 33-35

Galagan 0. (2014a) Using GIS for modeling of initial field contamination by heavy metals around highway areas (in Ukrainian). Bulletin of Lviv University. Geographic series 48: 75-79 / Галаган О. Використання ГІС при моделюванні первинного поля забруднення важкими металами приавтомагістральних територій. Вісник львівського університету. Серія географічна, 2014, вип. 48, С.75-79. https://doi.org/10.30970/vgg.2014.48.1296

Halahan A.A., Korohoda N.P. (2014b). Geoinformation modeling of the pollution of the near-earth layer of the atmosphere by heavy metals in the highway geosystems (in Russian). Complex problems of technosphere safety: International scientific-practical conference, Voronezh, 12 Nov 2014: Materials of the conf., Part IV: 127-131 / Галаган А.А., Корогода Н.П. Геоинформационное моделирование загрязнения приземного слоя атмосферы тяжелыми металлами в приавтомагистральных геосистемах / Комплексные проблемы техносферной безопасности: Междунар. науч. - практ. конф., Воронеж, 12 нояб. 2014: матер. конф., ч. IV., C.127-131

Halahan 0.0. (2015) Determination of the level of contamination in highway geosystems by heavy metals compounds through mathematical and cartographic modeling (in Ukrainian). Physic Geography and Geomorphology 4 (80):121-125 / Галаган 0.0. Визначення ступеня забруднення приавтомагістральних геосистем сполуками важких металів за допомогою математично-картографічного моделювання. Фізична географія та геоморфологія, 2015, вип. 4(80), С.121-125 
Halahan 0.0. (2017) The GIS modeling of near-motorways geosystems pollution with the heavy metals compounds. Thesis for a candidate of science degree in Geography, speciality 11.00.01 - Physical Geography, Geophysics and Geochemistry of Landscapes, Kyiv, 2016, 215p.

Halahan O., Korogoda N. (2018) Calculation of the amount of heave metals entering to the near-motoways geosystems with vehicle emissions (in Ukrainian). Bulletin of Taras Shevchenko National University of Kyiv. Geography.4 (73): 20 -24 / Галаган О., Корогода Н. Розрахунок кількості важких металів, що надходять у приавтомагістральні системи 3 викидами автотранспорту. Вісник Київського національного університету імені Тараса Шевченка. Географія, 2018, вип. 4 (73), C.20-24. https://doi.org/10.17721/1728-2721.2019.73.4

Kovalchuk I.P. et al. (2009) Geospatial modeling of the potential for degradation processes on arable lands (in Ukrainian). Land management and cadastre 4: 72 -82 / Ковальчук І.П. та ін. Геопросторове моделювання потенціалу розвитку деградаційних процесів на орних землях. Землеустрій і кадастр, 2009, №4, C.72-82

Methodendokumentation "Bodenkunde": Auswertungsmethoden zur Beurteilung der Empfindlichkeit und Belastbarkeit von Böden. // Geologisches Jahrbuch. Sonderhefte: Reihe G - Heft SG 1 - Ad-hoc-AGBoden. Volker Hennings. Herausgegeben von der Bundesanstalt für Geowissenschaften und Rohstoffe und den Staatlichen Geologischen Diensten in der Bundesrepublik Deutschland. - Verlag Schweizerbart, Stuttgart, 2000, 296 p.

Minkina T. M. et al. (2011) Accumulation of heavy metals in the soil system - a plant exposed to pollution (in Russian). Scientific Journal of the Russian Research Institute of Melioration Problems 4: 4-12 / Минкина Т. М. и др. Накопление тяжелых металлов в системе почва - растение в условиях загрязнения. Научный журнал Российского НИИ проблем мелиорации, 2011, № 4, С 4-12

Mkrtchyan 0. (2004) Geoinformation modeling of the slope process (in Ukrainian). Bulletin of Lviv University. Geographic se- ries 30 :188-193 / Мкртчян О. Геоінформаційне моделювання процесу схилової ерозії. Вісник львівського університету. Серія географічна, 2004, вип. 30, С.188-193

Nath T. N. (2015) Assessment of heavy metals concentration deposited in roadside tea cultivated soil in Dibrugarh District of Assam, India Journal of Chemistry and Chemical Sciences 5(1), 5-17. https://doi.org/10.5958/0974-4150.2015.00007.3

Pagotto C. et al. (2001) Heavy metal pollution of road dust and roadsidesoilnearamajor ruralhighway. Environmental Technology 22: 307-319. https://doi.org/10.1080/09593332208618280

Pivić R. N. et al. (2013) Assessment of Soil and Plant Contamination by Select Heavy Metals Along a Major European Highway. Polish Journal of Environmental Studies 22 (5): 1465-1472 Sorokina L.Yu. (2008) Principles of modeling of natural-anthropogenic processes in landscapes of zones of influence of technogenic objects (in Ukrainian). Ukrainian Geographical Journal, 1: 36-40. /Сорокіна Л.Ю. Принципи моделювання природно-антропогенних процесів у ландшафтах зон впливу техногенних об'єктів. Український географічний журнал, 2008, № 1, С. 36-40.

Svetlichny A.A. et al. (2004) Erosion Studies: Theoretical and Applied Aspects. Monograph (in Russian). Sumy, Ukraine: Univ. Book, 2004, 410 р. / Светличный А. А. та ін. Эрозиоведение: теоретические и прикладные аспекты: монография. Сумы: Унив. Кн., 2004, 410 c.

Viard B. et al. (2004) Integrated assessment of heavy metal (Pb, $\mathrm{Zn}, \mathrm{Cd}$ ) highway pollution: bioaccumulation in soil, Graminaceae and land snails. Chemosphere 55 (10): 1349-1359. https:// doi.org/10.1016/j.chemosphere.2004.01.003

Vlasov D.V. (2017) Metals and metalloids in particles of RM10 road dust of Eastern Moscow (in Russian). RUDN Journal of Ecology and Life Safety 25 (4): 529 - 539 / Власов Д.В. Металлы и металлоиды в частицах РМ10 дорожной пыли Восточной Москвы, 2017, Т.25 №4, С. 529 -539. https://doi. org/10.22363/2313-2310-2017-25-4-529-539 